\title{
Cognitive Dysfunction in Older Patients Undergoing Orthopedic Surgery: Analysis of Demographic, Clinical, and Intraoperative Risk Factors
}

\author{
Ortopedik Cerrahi Geçiren Yaşlı Hastalarda Bilişsel İşlev Bozukluğu: \\ Demografik, Klinik ve İntraoperatif Risk Faktörlerinin Analizi
}

\author{
Yasemin Tekdöş Şeker, (D) Yaser Pektaş, (1) Deniz Özel Bilgi, (1) Gökhan Sertçakacılar
}

University of Health Sciences Turkey, Bakırköy Dr. Sadi Konuk Training and Research Hospital, Clinic of Anesthesiology and Reanimation, İstanbul, Turkey

\begin{abstract}
Objective: We evaluated cognitive dysfunction in older patients undergoing orthopedic surgery regarding demographic, clinical, and intraoperative risk factors.

Methods: A total of 56 older patients (aged $>65$ years, mean \pm SD age: $75.1 \pm 6.8$ years, $75 \%$ were females) hospitalized for elective orthopedic surgery were included. Data on patient demographics (age, gender), comorbid diseases, planned surgery indications, American Society of Anesthesiologists (ASA) Classification category, intraoperative time (min), intraoperative blood loss ( $\mathrm{mL}$ ), and length of hospital stay (LOS; days) were recorded for each patient. Vital signs were recorded thrice, preoperatively, intraoperatively (every 15 min), and postoperatively (first hour), whereas pain was assessed based on visual analog scale (VAS) scores in the postoperative period $\left(1^{\text {st }} h, 12^{\text {th }} h, 36^{\text {th }} h\right)$. The Mini-Mental State Examination (MMSE) was administered preoperatively and in the postoperative $72^{\text {nd }} \mathrm{h}$ to assess cognitive status.

Results: Overall, a significant decrease was noted in MMSE scores from the preoperative to postoperative $\left(72^{\text {nd }} \mathrm{h}\right)$ period $[\mathrm{median}(\mathrm{minimum}$ maximum) 26 (12-30) vs. 23.5 (12-30), p<0.001]. The significant decline in MMSE scores after the operation was evident in each subgroup, regardless of the gender, ASA category, presence of comorbidity, or acute renal failure (average SD change from baseline ranged from -1.5 to $-1.0 ; p$-values ranged from 0.024 to $<0.001)$. Preoperative and postoperative MMSE scores were negatively correlated with age $(r=0.415$, $p=0.002$ and $r=-0.406, p=0.003$, respectively) and intraoperative time $(r=-0.511, p<0.001$ and $r=-0.428, p=0.002$, respectively).

Conclusion: Our findings revealed the likelihood of postoperative cognitive dysfunction in older patients undergoing orthopedic surgery, regardless of gender, comorbidities, or ASA category. However, there was an increased risk of postoperative cognitive decline with increased patient age and longer intraoperative time.
\end{abstract}

Keywords: Postoperative cognitive dysfunction, orthopedics, older patients, age, comorbidity, intraoperative characteristics

\section{öz}

Amaç: Ortopedik cerrahi geçiren yaşlı hastalarda kognitif disfonksiyonu demografik, klinik ve intraoperatif risk faktörleri açısından değerlendirmeyi amaçladık.

Gereç ve Yöntem: Elektif ortopedik cerrahi için hastaneye yatırılan toplam 56 yaşlı hasta (>65 yaş, ortalama \pm SS yaş: $75,1 \pm 6.8$ yıl, $\% 75$ kadın) dahil edildi. Hastaların demografik özellikleri (yaş, cinsiyet), komorbid hastalıkları, planlanan cerrahi endikasyonları, Amerikan Anesteziyologlar Derneği (ASA) Sınıflandırma kategorisi, intraoperatif süre (dakika), intraoperatif kan kaybı ( $\mathrm{mL}$ ), hastanede kalış süresi her hastada kaydedildi. Hayati bulgular ardışık şekilde üç kez kaydedildi; preoperatif, intraoperatif (15. dakika) ve postoperatif (1. saat), ağrı postoperatif dönemde (1. saat, 12. saat, 36. saat) görsel analog skala (VAS) skorlarına göre değerlendirildi. Bilişsel durumu değerlendirmek için ameliyat öncesi ve ameliyat sonrası 72. saatte mini mental durum testi (MMSE) yapıldı.

Bulgular: Genel olarak, MMSE skorlarında preoperatif dönemden postoperatif (72. saat) döneme [medyan (minimum-maksimum) 26 (12-30) ve 23,5 (12-30), p<0,001] arasında anlamlı bir düşüş kaydedildi. Cinsiyet, ASA kategorisi, komorbidite varlığı veya akut böbrek yetmezliği varlığından bağımsız olarak her alt grupta operasyondan sonra MMSE puanlarında önemli düşüş belirgindi (başlangıca göre ortalama SS değişikliği -1,5 ile

Address for Correspondence: Yasemin Tekdöş Şeker, University of Health Sciences Turkey, Bakırköy Dr. Sadi Konuk Training and Research Hospital, Clinic of Anesthesiology and Reanimation, İstanbul, Turkey

Phone: +90 5324755154 E-mail: dr.tekdosyasemin@gmail.com ORCID ID: orcid.org/0000-0001-6924-9814

Cite as: Tekdöş Şeker Y, Pektaş Y, Özel Bilgi D, Sertçakacılar G. Cognitive Dysfunction in Older Patients Undergoing Orthopedic Surgery: Analysis of Demographic, Clinical, and Intraoperative Risk Factors. Med J Bakirkoy 2021;17:190-196

Received: 20.02.2021

Accepted: 08.09.2021 
$-1,0$ arasında değişmekteydi; $p$ değerleri 0,024 ve $<0,001$ ). Preoperatif ve postoperatif MMSE skorları yaş (sırasıyla; $r=-0,415, p=0,002$ ve $r=-$ $0,406, p=0,003$ ) ve intraoperatif süre (sırasıyla; $r=-0,511, p<0,001$ ve $r=-0,428, p=0,002$ ).

Sonuç: Bulgularımız ortopedik cerrahi geçiren yaşı hastalarda cinsiyet, komorbidite veya ASA kategorisine bakılmaksızın postoperatif kognitif disfonksiyon olasıığının, hasta yaşının artması ve intraoperatif sürenin uzaması ile postoperatif bilişsel gerileme riskinin artı̆ğını ortaya koymuştur.

Anahtar Kelimeler: Postoperatif kognitif disfonksiyon, ortopedi, yaşlılık, yaş, komorbidite, intraoperative bulgular

\section{INTRODUCTION}

Postoperative cognitive dysfunction (POCD) refers to cognitive impairment affecting orientation, perception, attention, consciousness, and judgment that develop after anesthesia and surgery $(1,2)$. It is a commonly recognized clinical phenomenon, particularly among older people with $40 \%$ and $10 \%$ rates in those over 60 years of age at discharge and the third-month post-discharge, respectively (2-4).

Alongside the risk of permanent cognitive dysfunction, the development of POCD in older patients has also been associated with prolonged hospital recovery, increased morbidity, and delays in functional recovery $(1,5,6)$.

Given the aging of the population, an increasingly higher number of older patients are undergoing complex surgical procedures with advances in medicine, surgical techniques, and anesthetic care. Therefore, addressing the etiology, pathogenesis, and risk factors of POCD in older surgical patients has become clinically significant in developing appropriate preventive measures $(2,4,6)$.

Orthopedic surgery is considered to have a particular role concerning the risk of postoperative cognitive impairment given the high prevalence of cerebral microemboli during procedures such as total knee replacements $(1,7,8)$. This study was designed to evaluate cognitive dysfunction in older patients undergoing orthopedic surgery regarding demographic, clinical, and intraoperative risk factors.

\section{METHODS}

\section{Study Population}

A total of 56 older patients (aged $>65$ years, mean \pm SD age: $75.1 \pm 6.8$ years, $75 \%$ were females) hospitalized for elective orthopedic surgery were included in this prospective crosssectional study conducted between April 2018 and October 2018. Patients with known cognitive dysfunction and foreign patients who did not speak Turkish were excluded from the study. Written informed consent was obtained from each subject following a detailed explanation of the objectives and protocol of the study conducted in accordance with the ethical principles stated in the "Declaration of Helsinki" and approved by the institutional ethics committee.

\section{Assessments}

Data on patient demographics (age, gender), comorbid diseases, planned surgery indications, American Society of Anesthesiologists (ASA) Classification category, intraoperative time ( $\mathrm{min})$, intraoperative blood loss $(\mathrm{mL})$, and length of hospital stay (LOS; days) were recorded for each patient. Heart rate (bpm), systolic, diastolic and mean arterial blood pressure $(\mathrm{mmHg})$ were recorded thrice; preoperatively, intraoperatively (every $15 \mathrm{~min}$ ), and postoperatively (first hour), while hemoglobin $(\mathrm{g} / \mathrm{dL}$ ) and hematocrit (\%) levels were also measured preoperatively and postoperatively. Pain was assessed based on visual analog scale (VAS) scores in the postoperative period (1 $1^{\text {st }}$ $h, 12^{\text {th }} \mathrm{h}, 36^{\text {th }} \mathrm{h}$ ). The mini-mental state examination (MMSE) was administered preoperatively and in the postoperative $72^{\text {nd }} \mathrm{h}$ to assess cognitive status.

\section{Mini-Mental State Examination}

MMSE, one of the most widely used screening instruments for estimating the severity of cognitive impairment, is an 11-item measure comprising five domains (orientation, registration, attention and calculation, recall, and language) of cognitive function. The MMSE total score ranges from 0 to 30 , with a lower score indicating a higher degree of cognitive impairment (9-11).

\section{Statistical Analysis}

The statistical analysis was performed using IBM SPSS Statistics for Windows, version 25.0 (IBM Corp., Armonk, NY) and PAST (Paleontological Statistics) Software Package (12). The Mann-Whitney $U$ test and Kruskal-Wallis test with the Monte Carlo simulation technique analyzed numerical variables. The change over time was evaluated by the Wilcoxon test for two repeated measurements and by Friedman's Two-Way test with the Monte Carlo simulation and post hoc Dunn's test for more than two repeated measurements. A correlation analysis was performed via partial correlation analysis. Data were expressed as "mean \pm standard deviation (SD)," median (minimum-maximum), and percent (\%) where appropriate. A $p<0.05$ was considered statistically significant. 


\section{RESULTS}

\section{Baseline Characteristics, Intraoperative Data, and Hospital Stay}

Overall, the median age was 75 years (range, 65-92 years) and females comprised $75 \%$ of the study population. Comorbidities were evident in $50 \%$ of patients (hypertension in $25.0 \%$ ), whereas acute renal failure was noted in $12.5 \%$ of patients. The ASA category was II in $42.9 \%$ of patients, and total hip replacement (39.3\%) was the most common indication for surgery (Table 1).

The median intraoperative time, intraoperative blood loss, and LOS were $100 \mathrm{~min}$ (range, 60-180 min), $150 \mathrm{~mL}$ (range, 50-600 mL), and eight days (range, 4-27 days), respectively (Table 1).

\section{Pre- vs. Postoperative Assessment for Hemogram Findings, Vital Signs, and Pain Scores}

When compared with median (min-max) preoperative values, a significant decrease was noted in both hemoglobin [from 12.05 (8.9-15.9) $\mathrm{g} / \mathrm{dL}$ to $9.5(8.1-15.2) \mathrm{g} / \mathrm{dL}, \mathrm{p}<0.001$ ] and hematocrit [from $37.6 \%$ (28.4\%-46.7\%) to $30.05 \%$ (24.2\%$43.9 \%), p<0.001)$ levels in the postoperative period. The median (min-max) systolic blood pressure [135 (65-175) vs. 140 (94-178] $\mathrm{mmHg}, \mathrm{p}<0.001]$ and diastolic blood pressure [78.5 (55-148) vs. $71(60-98) \mathrm{mmHg}, p<0.05]$ levels were significantly lower in the intraoperative $15^{\text {th }}$ min compared with preoperative values, with no significant change between pre- and postoperative records in vital signs.

VAS pain scores were significantly higher in the postoperative $36^{\text {th }}$ hour compared with postoperative first and $12^{\text {th }}$ hour values [median (min-max) 5 (3-8) vs. 3 (2-4) and 4.5 (2-7); $p<0.001$ and $p<0.05$, respectively]. VAS scores in the postoperative $12^{\text {th }}$ hour were also significantly higher than in the postoperative first hour $(p<0.001)$ (Table 2).

\section{MMSE Scores According to Baseline Characteristics}

Overall, a significant decrease was noted in MMSE scores from preoperative to postoperative $\left(72^{\text {nd }} \mathrm{h}\right)$ period [median (min-max) 26 (12-30) vs. 23.5 (12-30), $p<0.001$ ]. The significant decline in MMSE scores after the operation was evident in each subgroup, regardless of gender, ASA category, presence of comorbidity, or acute renal failure (average SD change from baseline ranged from -1.5 to $-1.0 ; p$-values ranged from 0.024 to $<0.001$ ) (Table 3 ).

No significant difference was noted in preoperative MMSE scores, postoperative MMSE scores, and change from baseline according to gender, ASA category, and presence of comorbidity or acute renal failure (Table 3 ).

\section{Correlation of MMSE Scores with Study Variables}

Correlation analysis as adjusted for gender, ASA category, comorbidity and acute renal failure revealed that preoperative and postoperative MMSE scores were negatively correlated with age $(r=-0.415, p=0.002$ and $r=-$

Table 1. Baseline characteristics, intraoperative data, and hospital stay

\begin{tabular}{|c|c|c|}
\hline \multirow{2}{*}{ Age (year) } & Mean \pm SD & $75.1 \pm 6.8$ \\
\hline & Median (min-max) & $75(65-92)$ \\
\hline \multirow{2}{*}{ Gender, n (\%) } & Female & $42(75.0)$ \\
\hline & Male & $14(25.0)$ \\
\hline \multirow{3}{*}{ ASA category, $\mathrm{n}(\%)$} & II & $24(42.9)$ \\
\hline & III & $21(37.5)$ \\
\hline & IV & $11(19.6)$ \\
\hline \multirow{8}{*}{ Comorbidity, n (\%) } & None & $28(50.0)$ \\
\hline & $>3$ & $2(3.6)$ \\
\hline & HT & $14(25.0)$ \\
\hline & $\mathrm{HT}+\mathrm{DM}$ & $5(8.9)$ \\
\hline & $\mathrm{CHF}$ & $3(5.4)$ \\
\hline & Stroke & $2(3.6)$ \\
\hline & DM & $1(1.8)$ \\
\hline & Hypothyroidism & $1(1.8)$ \\
\hline \multirow{7}{*}{$\begin{array}{l}\text { Indication for surgery, } \\
\text { n (\%) }\end{array}$} & THR & $22(39.3)$ \\
\hline & PHA & $1(1.8)$ \\
\hline & TKP & $19(33.9)$ \\
\hline & ORIF & $7(12.5)$ \\
\hline & Upper & $1(1.8)$ \\
\hline & MMR & $3(5.4)$ \\
\hline & Other & $3(5.4)$ \\
\hline \multicolumn{2}{|c|}{ Postoperative infection, n (\%) } & $2(3.6)$ \\
\hline \multicolumn{2}{|l|}{ LFT, n (\%) } & $1(1.8)$ \\
\hline \multicolumn{2}{|l|}{ Acute renal failure, $\mathrm{n}(\%)$} & $7(12.5)$ \\
\hline \multirow{2}{*}{$\begin{array}{l}\text { Intraoperative time } \\
\text { (min) }\end{array}$} & Mean \pm SD & $108.0 \pm 34.8$ \\
\hline & Median (min-max) & $100(60-180)$ \\
\hline \multirow{2}{*}{$\begin{array}{l}\text { Intraoperative blood } \\
\text { loss }(\mathrm{mL})\end{array}$} & Mean \pm SD & $183.9 \pm 108.3$ \\
\hline & Median (min-max) & $150(50-600)$ \\
\hline \multirow{2}{*}{$\begin{array}{l}\text { Length of hospital stay } \\
\text { (day) }\end{array}$} & Mean \pm SD & $9.3 \pm 4.3$ \\
\hline & Median (min-max) & $8(4-27)$ \\
\hline
\end{tabular}

ASA: American society of anesthesiologists, DM: Diabetes mellitus, HT: Hypertension, CHF: Congestive heart failure, THR: Total hip replacement, PHA: Partial hip replacement, TKP: Total knee prosthesis, ORIF: Open reduction internal fixation, Upper: Upper extremity surgeon, MMR: Medial meniscus repair, LFT: Liver function tests, SD: Standard deviation, Min:

Minimum, Max: Maximum 
$0.406, p=0.003$, respectively) and intraoperative time ( $r=-$ $0.511, p<0.001$ and $r=-0.428, p=0.002$, respectively) (Table 4). No significant correlation of MMSE scores was noted with intraoperative blood loss or LOS (Table 4).

\section{DISCUSSION}

Our findings in a cohort of older patients undergoing orthopedic surgery revealed a significant decrease in MMSE scores $72 \mathrm{~h}$ after surgery, regardless of gender, ASA category, or presence of comorbidity, or ARF.

Table 2. Pre- vs. postoperative assessment for hemogram findings, vital sings and pain scores

\begin{tabular}{|c|c|c|c|c|}
\hline & Preoperative & Postoperative & & $p$ \\
\hline Hemoglobin (g/dL) & $12.05(8.9-15.9)$ & $9.5(8.1-15.2)$ & & $<0.001^{1}$ \\
\hline \multirow[t]{2}{*}{ Hematocrit (\%) } & $37.6(28.4-46.7)$ & 30.05 (24.2-43.9) & & $<0.001^{1}$ \\
\hline & Preoperative & Intraoperative $\left(15^{\text {th }} \mathrm{min}\right)$ & Postoperative $\left(1^{\text {st }} h\right)$ & \\
\hline Heart rate (bpm) & $74(62-126)$ & $80.5(60-100)$ & $80(64-95)$ & $0.099^{2}$ \\
\hline Systolic BPP & $140(94-178)$ & $135(65-175)^{* *}$ & $138(100-168)$ & $0.004^{2}$ \\
\hline \multirow[t]{2}{*}{ Diastolic BP } & $78.5(55-148)$ & $71(60-98)^{*}$ & $72(45-106)$ & $0.026^{2}$ \\
\hline & Postoperative & & & \\
\hline \multirow{2}{*}{ VAS Pain scores } & $12^{\text {th }} \mathrm{h}$ & $36^{\text {th }} \mathrm{h}$ & & \\
\hline & $3(2-4)^{q q, w}$ & $4.5(2-7)^{a}$ & & $<0.001^{2}$ \\
\hline
\end{tabular}

Data are shown as median (min-max). VAS: Visual analog scale; BP: Blood pressure

${ }^{1}$ Wilcoxon-Signed Ranks test (Monte Carlo), ${ }^{2}$ Friedman test (Monte Carlo), Post Hoc test: Dunn's test ${ }^{*} \mathrm{p}<0.05$ and ${ }^{* *} \mathrm{p}<0.01$; compared to preoperative values ${ }^{9} p<0.05$ and ${ }^{9 q} p<0.001$; compared to $36^{\text {th }}$ hour values ${ }^{w} p<0.001$; compared to $12^{\text {th }}$ hour values

Table 3. MMSE scores according to baseline characteristics

\begin{tabular}{|c|c|c|c|c|c|}
\hline \multirow{3}{*}{$\begin{array}{l}\text { Preoperative } \\
\text { median (min-max) }\end{array}$} & & \multicolumn{4}{|l|}{ MMSE scores } \\
\hline & & \multirow{2}{*}{$\begin{array}{l}\text { Postoperative } \\
\left(72^{\text {nd }} h\right)\end{array}$} & \multirow{2}{*}{$\begin{array}{l}\text { Change from baseline } \\
\text { median (min-max) }\end{array}$} & \multirow{2}{*}{$\begin{array}{l}\text { p } \\
\text { pre vs. postop }\end{array}$} & \\
\hline & & & & & \\
\hline Total & & $26(12-30)$ & $23.5(12-30)$ & $-1(-10-6)$ & $<0.001^{3}$ \\
\hline \multirow{3}{*}{ Gender } & Female & $26(12-30)$ & $26(12-30)$ & $-1(-10-6)$ & $<0.001^{3}$ \\
\hline & Male & $23(13-30)$ & $21.5(12-29)$ & $-1.5(-6-1)$ & $0.001^{3}$ \\
\hline & $\mathrm{p}$ & $0.136^{1}$ & $0.136^{1}$ & $0.237^{1}$ & \\
\hline \multirow{4}{*}{ ASA category } & II & $25.5(13-30)$ & $23.5(12-30)$ & $-1(-6-1)$ & $<0.001^{3}$ \\
\hline & III & $28(12-30)$ & $26(16-30)$ & $-1(-6-6)$ & $0.004^{3}$ \\
\hline & IV & $25(14-30)$ & $20(12-30)$ & $-1(-10-0)$ & $0.004^{3}$ \\
\hline & $\mathrm{p}$ & $0.295^{2}$ & $0.106^{2}$ & $0.459^{2}$ & \\
\hline \multirow{3}{*}{ Comorbidity } & Absent & $25.5(12-30)$ & $23(12-30)$ & $-1(-6-6)$ & $<0.001^{3}$ \\
\hline & Present & $26(14-30)$ & $24.5(12-30)$ & $-1(-10-1)$ & $<0.001^{3}$ \\
\hline & $\mathrm{p}$ & $0.307^{1}$ & $0.669^{1}$ & $0.582^{1}$ & \\
\hline \multirow{3}{*}{ Acute renal failure } & Absent & $26(12-30)$ & $23(12-30)$ & $-1(-10-6)$ & $<0.001^{3}$ \\
\hline & Present & $28(21-30)$ & $27(16-30)$ & $-1(-6-0)$ & $0.024^{3}$ \\
\hline & $\mathrm{p}$ & $0.314^{1}$ & $0.294^{1}$ & $0.945^{1}$ & \\
\hline
\end{tabular}

ASA: American society of anesthesiologists, MMSE: Mini-Mental state examination

${ }^{1}$ Mann-Whitney U test (Monte Carlo), ${ }^{2}$ Kruskal-Wallis test (Monte Carlo), ${ }^{3}$ Wilcoxon Signed Ranks test (Monte Carlo) 


\begin{tabular}{|c|c|c|c|c|c|c|}
\hline & \multicolumn{6}{|c|}{ MMSE scores } \\
\hline & \multicolumn{2}{|c|}{ Preoperative } & \multicolumn{2}{|c|}{ Postoperative } & \multicolumn{2}{|c|}{ Change from baseline } \\
\hline & $r$ & $p$ & $r$ & $\mathrm{p}$ & $r$ & $p$ \\
\hline Age & -0.415 & 0.002 & -0.406 & 0.003 & -0.019 & 0.895 \\
\hline Intraoperative time (min) & -0.511 & $<0.001$ & -0.428 & 0.002 & 0.133 & 0.346 \\
\hline Intraoperative blood loss (mL) & -0.182 & 0.195 & -0.097 & 0.494 & 0.169 & 0.230 \\
\hline Length of hospital stay (day) & -0.193 & 0.169 & -0.179 & 0.204 & 0.013 & 0.925 \\
\hline
\end{tabular}

Adjusted for gender, ASA category, comorbidity, and acute renal failure. Partial Correlation test, r: correlation coefficient, MMSE: MiniMental state examination

When adjusted for gender, ASA category, or presence of comorbidity and ARF, MMSE scores were negatively correlated with age and intraoperative time. In contrast, no correlation of MMSE scores was noted with intraoperative blood loss or LOS. MMSE scores did not differ concerning gender, ASA category, or presence of comorbidity in the pre or postoperative period.

A postoperative decline of $\geq 1$ SD from baseline MMSE scores in our patients indicated the likelihood of cognitive impairment in older patients undergoing orthopedic surgery. However, an increase in age and longer intraoperative time were determined as the two risk factors for the postoperative decline in MMSE scores. Hence, our findings emphasize that advanced age and complexity of the surgical procedure, rather than gender and comorbidities, were associated with a higher risk of new cognitive impairment arising after a surgical procedure in older orthopedic patients. This seems consistent with consideration of advanced age and extensive surgery with a higher risk of postoperative POCD in apparently previously cognitively well patients undergoing surgery with the most marked increase of risk among those over 65 years of age $(2,13)$. In a systematic review of studies in surgery patients, increasing age was the most common risk factor for POCD. In contrast, the duration and type of surgery (cardiac, orthopedic, and vascular) were also reported among risk factors (13).

Indeed, a systematic review of 19 studies in 6477 patients concluded that the prevalence of POCD was $11.7 \%$ for non-cardiac surgery at threemonths of follow-up (14). However, older patients undergoing higher risk surgery are considered to have a higher risk. The POCD prevalence in patients undergoing elective hip surgery is estimated to be $22 \%(15)$.

Notably, in the older population undergoing hip fracture surgery, POCD, along with postoperative delirium, have been reported to be the two frequent complications leading to increased risk of morbidity, mortality, and prolonged hospital stays (16-18).
While potentially anesthetic-dependent modifiable factors (i.e., hypoxia, hypotension, and altered cerebral perfusion) have been postulated as contributing to POCD, there is no conclusive evidence $(13,19,20)$. Indeed, hypotension as a common cause of cerebral hypoperfusion has been investigated regarding its relation to POCD, but the potential impact of prolonged hypotension was not confirmed in these studies (19,21-23). Accordingly, while there was a significant but transient decline in systolic and diastolic blood pressure intraoperatively, blood pressure was maintained at preoperative levels postoperatively in our patients. In addition, while a significant decline was noted in hemoglobin and hematocrit levels after the operation, there was no significant impact of intraoperative blood loss on MMSE findings.

Given the association of vascular risk factors (i.e., hypertension, obesity, diabetes mellitus) with cognitive decline in the general population, their optimization may have a role in lowering the risk of POCD $(13,19,24)$. Our findings revealed comorbidities (i.e., diabetes, hypertension, congestive heart failure, stroke) in $50 \%$ of patients, whereas no significant impact of the presence of comorbidity on the postoperative decline in MMSE scores and on preoperative MMSE scores. These seem notable given that diabetes mellitus, hypertension, obesity, smoking, depression, cognitive inactivity, and physical inactivity are considered critical modifiable risk factors for cognitive dysfunction in Alzheimer's disease with the potential impact of related lifestyle interventions on cognitive improvement (25-27). Our findings revealed no such impact of comorbidities on the likelihood or severity of POCD among older orthopedic surgery patients.

Our findings based on assessing cognitive status $72 \mathrm{~h}$ after surgery seem consistent with considering POCD to be most prevalent in the immediate postoperative period and highly prevalent up to three months postoperatively, and mostly 
resolving within days to weeks $(6,13,28,29)$. Notably, while POCD may also persist 1-2 years after surgery, it has been considered to be reversible and rarely persists in the longer (10 years) term $(6,13,28,29)$.

Notably, while the variance in the 7-day, 3-month, or 12-month cognitive assessment in the same patient has been considered likely, the longitudinal assessment has revealed that a single diagnosis of cognitive decline is associated with a higher incidence even with this fluctuating pattern of long-term dementia $(25,30,31)$. Besides, while POCD is generally transient, it lasts longer and affects everyday life more severely in patients over age 60 (32). Also, the presence of POCD on discharge has been associated with diminished quality of life and increased risk of mortality within one year after surgery $(2,3)$.

This also seems notable given the increasingly recognized role of perioperative consultation with older specialists among older patients undergoing major surgery to prevent POCD and improve quality of life (13). In orthopedic surgery, they are associated with good outcomes in hip fracture patients (33).

Although the MMSE was essentially developed as a cognitive screening tool, it performs well as a screening tool for dementia. Therefore, it was suggested that the MMSE has a limited role in assessing cognitive decline after anesthesia and surgery $(13,25)$. It has been widely used as a tool to detect POCD, given the ease of administration (6-8 minutes) $(25,34)$ and the consideration of the purpose of postoperative neuropsychological testing to detect the presence of general, rather than specific, changes in cognitive functioning (35).

Use of single-point testing for cognitive status before orthopedic surgery has been considered to give an incorrect opinion about patients' cognitive trajectory, given the likelihood of preoperative pain (i.e., for a patient about to undergo total hip replacement) to have a considerable impact on cognition and thus the impact of the postoperative reduction in pain and improved mobility on cognitive measures $(13,24)$. This seems notable given the significant increase in VAS pain scores from the postoperative first $h$ to $36^{\text {th }} \mathrm{h}$ in our patients.

Nonetheless, the heterogeneity of study populations, definition of cognitive impairment, instruments used to measure cognitive performance, and follow-up periods have been the major challenges limiting the likelihood of generalizing from the study findings available on POCD $(2,13)$.

\section{CONCLUSIONS}

In conclusion, our findings revealed the likelihood of POCD in older patients undergoing orthopedic surgery, regardless of gender, comorbidities, or ASA category. However, there was an increased risk of postoperative cognitive decline with increased patient age and longer intraoperative time. This emphasizes the critical role of improved perioperative geriatric care in providing guidance and early recognition of risk factors among older patients prone to POCD. Largerscale longitudinal clinical studies employing standardized test instruments are necessary to determine the risk for further cognitive deterioration in the longer term and develop strategies to minimize the cognitive impact for a better quality of life in older surgical patients.

\section{ETHICS}

Ethics Committee Approval: The study were approved by the University of Health Sciences Turkey, Bakırköy Dr. Sadi Konuk training and Research Hospital of Local Ethics Committee (protocol number: 2018/126-17.05.2018).

Informed Consent: Consent form was filled out by all participants.

\section{Authorship Contributions}

Surgical and Medical Practices: G.S., Y.P., Concept: Y.T.Ş., Design: Y.T.Ş., Data Collection or Processing: D.Ö.B., G.S., Y.P., Analysis or Interpretation: Y.T.Ş., Literature Search: Y.T.Ş., Writing: Y.T.Ş.,

Conflict of Interest: No conflict of interest was declared by the authors.

Financial Disclosure: The authors declared that this study received no financial support.

\section{REFERENCES}

1. Kotekar N, Shenkar A, Nagaraj R. Postoperative cognitive dysfunction - current preventive strategies. Clin Interv Aging 2018;13:2267-73.

2. Rundshagen I. Postoperative cognitive dysfunction. Dtsch Arztebl Int 2014;111:119-25.

3. Monk TG, Weldon BC, Garvan CW, Dede DE, van der Aa MT, Heilman KM, et al. Predictors of cognitive dysfunction after major noncardiac surgery. Anesthesiology 2008;108:18-30.

4. Chi YL, Li ZS, Lin CS, Wang Q, Zhou YK. Evaluation of the postoperative cognitive dysfunction in elderly patients with general anesthesia. Eur Rev Med Pharmacol Sci 2017;21:1346-54.

5. Newman MF, Kirchner JL, Phillips-Bute B, Gaver V, Grocott H, Jones $\mathrm{RH}$, et al. Longitudinal assessment of neurocognitive function after coronary-artery bypass surgery. N Engl J Med 2001;344:395-402.

6. Grape S, Ravussin P, Rossi A, Kern C, Steiner LA. Postoperative cognitive dysfunction. Trends Anaesth Crit Care 2012;2:98-103. 
7. Sulek CA, Davies LK, Enneking FK, Gearen PA, Lobato EB Cerebral microembolism diagnosed by transcranial Doppler during total knee arthroplasty: correlation with transesophageal echocardiography. Anesthesiology 1999;91:672-6.

8. Ogino Y, Tatsuoka Y, Matsuoka R, Nakamura K, Nakamura H, Tanaka $\mathrm{C}$, et al. Cerebral infarction after deflation of a pneumatic tourniquet during total knee replacement. Anesthesiology 1999;90:297-8.

9. Rovner BW, Folstein MF. Mini-mental state exam in clinical practice. Hosp Pract (Off Ed) 1987;22:99-110.

10. Tombaugh TN, Mclntyre NJ. The mini-mental state examination: a comprehensive review. J Am Geriatr Soc 1992;40:922-35.

11. Güngen C, Ertan T, Eker E, Yaşar R, Engin F. Standardize Mini Mental test'in türk toplumunda hafif demans tanisinda geçerlik ve güvenilirliği [Reliability and validity of the standardized Mini Mental State Examination in the diagnosis of mild dementia in Turkish population]. Turk Psikiyatri Derg 2002;13:273-81.

12. Hammer Q, Harper D, Ryan PD, 2001. Past: Paleontological Statistics Software Package for Education and Data Analysis. Palaeontologia Electronica 2011:4:1-9. http://palaeo-electronica. org/2001_1/past/issue1_01.htm.

13. Needham MJ, Webb CE, Bryden DC. Postoperative cognitive dysfunction and dementia: what we need to know and do. $\mathrm{Br} J$ Anaesth 2017;119 (Suppl 1):i115-25.

14. Paredes S, Cortínez L, Contreras V, Silbert B. Post-operative cognitive dysfunction at 3 months in adults after non-cardiac surgery: a qualitative systematic review. Acta Anaesthesiol Scand 2016;60:1043-58

15. Chow WB, Rosenthal RA, Merkow RP, Ko CY, Esnaola NF; American College of Surgeons National Surgical Quality Improvement Program; American Geriatrics Society. Optimal preoperative assessment of the geriatric surgical patient: a best practices guideline from the American College of Surgeons National Surgical Quality Improvement Program and the American Geriatrics Society. J Am Coll Surg 2012;215:453-66.

16. Edlund A, Lundström $M$, Lundström G, Hedqvist B, Gustafson Y. Clinical profile of delirium in patients treated for femoral neck fractures. Dement Geriatr Cogn Disord 1999;10:325-9.

17. Sanguineti VA, Wild JR, Fain MJ. Management of postoperative complications: general approach. Clin Geriatr Med 2014;30:261-70.

18. Kratz T, Heinrich M, Schlauß E, Diefenbacher A. Preventing postoperative delirium. Dtsch Arztebl Int 2015;112:289-96.

19. Moller JT, Cluitmans P, Rasmussen LS, Houx P, Rasmussen H, Canet $\mathrm{J}$, et al. Long-term postoperative cognitive dysfunction in the elderly ISPOCD1 study. ISPOCD investigators. International Study of Post-Operative Cognitive Dysfunction. Lancet 1998;351:857-61.

20. van Harten AE, Scheeren TW, Absalom AR. A review of postoperative cognitive dysfunction and neuroinflammation associated with cardiac surgery and anaesthesia. Anaesthesia 2012;67:280-93.

21. Pappa M, Theodosiadis N, Tsounis A, Sarafis P. Pathogenesis and treatment of post-operative cognitive dysfunction. Electron Physician 2017;9:3768-75.
22. Rollason WN, Robertson GS, Cordiner CM, Hall DJ. A comparison of mental function in relation to hypotensive and normotensive anaesthesia in the elderly. $\mathrm{Br} \mathrm{J}$ Anaesth 1971;43:561-6.

23. Thompson GE, Miller RD, Stevens WC, Murray WR. Hypotensive anesthesia for total hip arthroplasty: a study of blood loss and organ function (brain, heart, liver, and kidney). Anesthesiology 1978:48:91-6.

24. Nadelson MR, Sanders RD, Avidan MS. Perioperative cognitive trajectory in adults. Br J Anaesth 2014;112:440-51.

25. Evered LA, Silbert BS. Postoperative Cognitive Dysfunction and Noncardiac Surgery. Anesth Analg 2018;127:496-505.

26. Deckers K, van Boxtel MP, Schiepers OJ, de Vugt M, Muñoz Sánchez JL, Anstey KJ, et al, Köhler S. Target risk factors for dementia prevention: a systematic review and Delphi consensus study on the evidence from observational studies. Int J Geriatr Psychiatry 2015;30:234-46.

27. Ngandu T, Lehtisalo J, Solomon A, Levälahti E, Ahtiluoto S, Antikainen $\mathrm{R}$, et al. A 2 year multidomain intervention of diet, exercise, cognitive training, and vascular risk monitoring versus control to prevent cognitive decline in at-risk elderly people (FINGER): a randomised controlled trial. Lancet 2015;385:2255-63.

28. Abildstrom $H$, Rasmussen LS, Rentowl P, Hanning CD, Rasmussen $H$, Kristensen PA, et al. Cognitive dysfunction 1-2 years after noncardiac surgery in the elderly. ISPOCD group. International Study of Post-Operative Cognitive Dysfunction. Acta Anaesthesiol Scand 2000:44:1246-51.

29. Steinmetz J, Siersma V, Kessing LV, Rasmussen LS; ISPOCD Group. Is postoperative cognitive dysfunction a risk factor for dementia? A cohort follow-up study. Br J Anaesth 2013;110 (Suppl 1):i92-7.

30. Roberts RO, Knopman DS, Mielke MM, Cha RH, Pankratz VS, Christianson TJ, et al. Higher risk of progression to dementia in mild cognitive impairment cases who revert to normal. Neurology. 2014;82:317-25

31. Lopez OL, Becker JT, Chang YF, Sweet RA, DeKosky ST, Gach MH, et al. Incidence of mild cognitive impairment in the Pittsburgh Cardiovascular Health Study-Cognition Study. Neurology 2012;79:1599-606.

32. Krenk L, Rasmussen LS, Kehlet H. New insights into the pathophysiology of postoperative cognitive dysfunction. Acta Anaesthesiol Scand 2010;54:951-6.

33. Grigoryan KV, Javedan H, Rudolph JL. Orthogeriatric care models and outcomes in hip fracture patients: a systematic review and meta-analysis. J Orthop Trauma 2014;28:e49-55.

34. Tsai TL, Sands LP, Leung JM. An Update on Postoperative Cognitive Dysfunction. Adv Anesth 2010;28:269-84.

35. Rasmussen LS, Larsen K, Houx P, Skovgaard LT, Hanning CD, Moller JT; ISPOCD group. The International Study of Postoperative Cognitive Dysfunction. The assessment of postoperative cognitive function. Acta Anaesthesiol Scand 2001;45:275-89. 